\title{
SECURITY AND COPYRIGHT INTEGRITY IN UHD CONTENT
}

Chair: Antonio Salles Neto, Coordenador do Núcleo Inteligência Antifraude da ABTA

Understanding risks to copyright and intellectual property in the unrestricted use of neutrality by the illegal industry. Cyber crime acts in the virtual world. It invades, it steals in the cloud, it receives, it resells the product and it evades in speed next to the light. How to inhibit virtual crime with legal processes of the material world, which reacts on the speed of people and rigid objects? 402/5000 Understanding risks to copyright and intellectual property in the unrestricted use of neutrality by the illegal industry. Cyber crime acts in the virtual world. It invades, it steals in the cloud, it receives, it resells the product and it evades in speed next to the light. How to inhibit virtual crime with legal processes of the material world, which reacts on the speed of people and rigid objects?

- MPACTS OF ILLEGAL IPTV OPERATIONS ON CONTENT PRODUCTION IN BRAZIL

Speaker: Marcelo Bechara - Director of Institutional Relations, Regulation and New Media - GLOBO Group

Market and regulatory vision of consequences on investments in content production, in the face of piracy threats in distribution.

- INTERNATIONAL LANDSCAPE - ILLEGAL EXPLOITATION OF COPYRIGHT IN IP NETWORKS

Speaker: Ygor Valerio - VP Legal and Content Protection LTAM - MPAA Motion Pictures Association

The vision of the film industry about how countries in Latin America and other continents are dealing with the illegal distribution of copyrighted content over the Internet. 


\section{- DIGITAL LAW AND MCI - MARCO CIVIL INTERNET Speaker: Daniel Pitanga - Advogado / Associate - Siqueira Castro Advogados}

Risks to copyright and intellectual property in the distribution of UHD content on the Internet, under the understanding of law and $\mathrm{MCl}$.

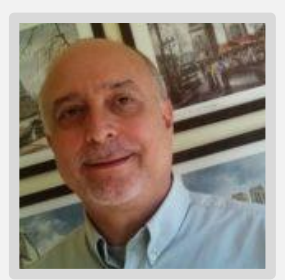

\section{Antonio Salles Neto, Coordenador do Núcleo Inteligência Antifraude da ABTA}

Pioneer in Cable TV in Brazil. Former CTO in companies such as NET, United Globalcom (LGI), Adelphia BR / Blue and Director of SETA-Brazilian PayTV Union. Coordinator of Anti-Fraud Intelligence Center at ABTA - cyber security for video content, since 2011.

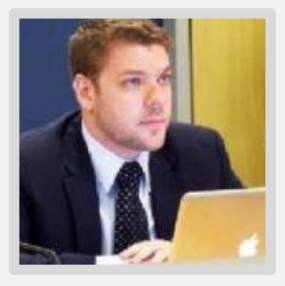

Marcelo Bechara - Director of Institutional Relations, Regulation and New Media - GLOBO Group

Marcelo Bechara is a lawyer with an MBA in Economic and Business Law from Fundação Getúlio Vargas and a specialization in Communication and Technology Law. He is a participant in the ILaw Program through the Berkman Center for Internet \& Society of Harvard Law School. Formerly attorney-general at Anatel, member of the Internet steering committee in Brazil - CGI.br and the Board of Directors of the Information and Coordination Center of PontoBr. He was Legal Consultant to the Ministry of Communications, President of the Organizing Committee of the I National Conference on Communication, Vice President of the Consultative Council of the National Telecommunications Agency - Anatel, having also held office as a Member of the Fiscal Council of ECT - the Brazilian Postal Service. He is certified in Intellectual Property Law by the World Intellectual Property Organization Academy..

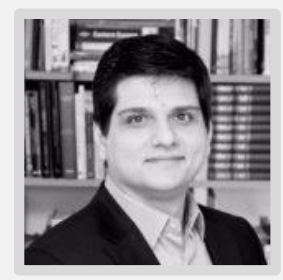

Ygor Valerio - VP Legal and Content Protection LTAM - MPAA - Motion Pictures Association Lawyer, graduated in Law from Largo São Francisco Law School - USP, specializing in intellectual property by FGV-SP. Co-coordinator of the ABPI Copyright Studies Committee and Legal Vice President and Content Protection for Latin America at the MPA-Motion Pictures Association. Worked in companies such as Adobe, Nokia and Microsoft. Author of several articles in the areas of law, technology and intellectual property

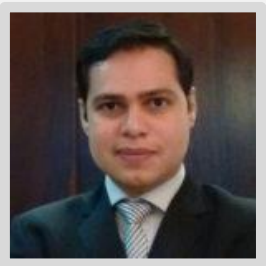

\section{Daniel Pitanga - Advogado / Associate - Siqueira Castro Advogados}

Daniel Pitanga is a Media Lawyer with more than 11 years of experience in the field of entertainment, internet, and technology. Senior Lawyer Associate at Siqueira Castro Advogados. LLM (Master of Laws) in Information Technology and Telecommunications Law (University of Southampton/UK). Postgraduate Diploma in Intellectual Property Law (PUC-Rio). Postgraduate certificate in Entertainment Law (UERJ). Vice-Chair from the Interactive Entertainment and Media Committee from ITechLaw (International Technology Law Association). Secretary-General of the Industrial Property and Piracy Committee at Brazilian Bar Association, Rio de Janeiro Section. Former Secretary-General of the Copyright, Immaterial Rights and Entertainment Committee at 
SET EXPO PROCEEDINGS - SETEP v. 3

(C) 2017 SET - Brazilian Society of Television Engineering / ISSN (Print): 2447-0481/ ISSN (Online): 2447-049X

Brazilian Bar Association, Rio de Janeiro Section. Member of the Brazilian Bar Association, Rio de Janeiro Section. Member of ITechLaw.

Cite this article:

Salles, A., Bechara, M., Valerio, Y. and Pitanga, D.; 2017. Security and Copyright Integrity in UHD Content. ISSN Print: 2447-0481. ISSN Online: 2447-049X. v.3. doi: 10.18580/setep.2017.16. Web Link: http://dx.doi.org/10.18580/setep.2017.16 